\title{
COMPARATIVE ANALYSIS OF THEORETICAL APPROACHES TO PROFESSIONAL TRAINING OF THE FUTURE CUSTOMS OFFICERS IN THE SYSTEM OF HIGHER EDUCATION OF UKRAINE AND POLAND
}

\begin{abstract}
The article deals with the content of future customs officers' professional training. Such notions as "training", "specialists' professional training", "customs officers' professional training". The article presents an overview of the scientific literature, theoretical analyzes of materials concerning the issues of future customs officers' professional training in the higher educational institutions of Ukraine and the Republic of Poland, still remaining open. The major scientific approaches of leading domestic and foreign scientists to study future customs officers' professional training have been characterized, in particular competence approach, functional approach, instrumental approach, learner-centred approach, axiological approach, historical and systematic-andcomprehensive approaches, theoretical generalization The conception of the research problem in the educational sphere of higher educational institutions has been theoretically generalised. The point of the article is focused on the fact that professional training of future specialists of customs authorities is a process of learning, understanding and specific knowledge, skills and proficiencies of future customs officers who perform the functions of future professional activities, fulfil their functions in accordance with their professional duties during customs service. Also it has been noted that professional training of future customs specialists is caused by personal, practical, functional, historical factors that it is important in the process of understanding this phenomenon and in the research and development processes.

Key words: customs officers, professional training, professional skills, competences, knowledge, skills, higher educational institution, the Republic of Poland, Ukraine.

\section{INTRODUCTION}

In terms of fast globalization processes in society there is professional competence of staff which is the one of the most important factors of innovation development in all spheres of life, because it is imposible to ensure reliability and stability of state economic system and its relevant results without a sufficient number of qualified professionals. Therefore, professional training of future customs officers as a focused process of professionalism formation is of great importance nowadays.

The theoretical analysis of literary sources on the issues of future customs officers' professional training demonstrates a solid amount of research findings by modern foreign and Ukrainian scientists where they raise it not only deliberately studying its content and and peculiarities, as well discussing it in the context of all spheres related to training, education and professional activities. However, there is no definite justification of this problem, so the issue of future customs officers' professional training remains open.
\end{abstract}




\section{THE AIM OF THE STUDY}

The aim of the study is the comparative analysis of theoretical approaches to professional training of the future customs officers in the system of higher education of Ukraine and Poland.

\section{THEORETICAL FRAMEWORK AND RESEARCH METHODS}

According to current Constitution of Ukraine, chapter II, article 53, the State ensures accessible and free pre-school, complete general secondary, vocational and higher education in state and communal educational establishments. The qualification "Customs Inspector" code is 3441 , as it is stated in the third chapter of the "Classification of occupations”, approved by Derzhspozhyvstandard № 327 (State provision standard) since July 28, 2010. In the educational perspective of the Republic of Poland in the light of the provisions of chapter IV, article 70 of the Constitution of the Republic of Poland guarantees that every citizen has the right to education that is free of charge, including higher education. The qualification "Customs officer" code ("Funkcjonariusz celny") is 3351, as it is stated in the "Classification of occupations", approved by the Decree of the Minister of Labour and Social Policy since March 27, 2010. Education must be both available to all learners and high-quality. Obtaining quality higher education has long been considered an important factor of impact on future professional activity, career and competitiveness.

In the modern world literature the activity of the customs authorities from different countries is studied by many scholars such as V. Chentsov, O. Fradynskyi, E. Hozhlinska, V. Komzyuk, N. Sidletska, M. Shpilska, I. Smirnov, S. Taranova, A. Voytseschuk, I. Yarmul and others.

During the theoretical study of the presenting problem we have used methods of organizing, comparative analysis, theoretical generalization and extrapolation.

\section{RESULTS}

A lot of scientists have analyzed the problem of definition of future customs officers' professional training: on the one hand, they specify its relation to education system; on the other hand, they point out peculiarities of interrelation among knowledge, competence and skills; and finally - its social role in a modern society. It is very important to note that scientists have identified a number of directions of the definition "professional training" during the analysis of various sources.

One of these directions is professional training of the future customs officers. It is viewed as both Ukrainian and Polish scientists from different sides: some authors study the forming of future customs officers' competence, others - the system of professional training. Analyzing various literary sources, we have classified the main concepts of Ukrainian scientists for the professional training definition of the future customers and its peculiar features (Table 1)

Thus, we consider necessary to analyze main characteristic features of future customs officers' professional training through each of the principal.

Table 1

Basic principles in specification of professional training of the future customs officers

\begin{tabular}{|c|c|}
\hline $\begin{array}{l}\text { Specification of professional training } \\
\text { of the future customs officers }\end{array}$ & Authors \\
\hline $\begin{array}{l}\text { Competent principle } \\
\text { Professional training of the future customs officers is a process of } \\
\text { learning and assimilation of general and specific knowledge, competence } \\
\text { and skills, guiding the future specialists to perform concrete professional } \\
\text { tasks }\end{array}$ & $\begin{array}{l}\text { O. Martsenyuk, } \\
\text { O. Myropolska, } \\
\text { S. Moroz, } \\
\text { O. Pavlenko }\end{array}$ \\
\hline
\end{tabular}




\begin{tabular}{|c|c|}
\hline $\begin{array}{l}\text { Functional principle } \\
\text { Professional training of the future customs officers is a process of } \\
\text { learning and professional organization of the future customs officials } \\
\text { through their acquisition of necessary knowledge and skills for work }\end{array}$ & V. Chentsov \\
\hline $\begin{array}{l}\text { Instrumental principle } \\
\text { Professional training of the future customs officers is a process of } \\
\text { possession by system skills to solve some ordinary tasks of professional } \\
\text { activity while doing productive functions for the effective acting of their } \\
\text { professional duties }\end{array}$ & $\begin{array}{l}\text { N. Kalynyuk, } \\
\text { O. Tryakina }\end{array}$ \\
\hline $\begin{array}{l}\text { Individual principle } \\
\text { Professional training of the future customs officers is a } \\
\text { specialized improvement of available education, developing, } \\
\text { intensification, expansion and updating professional knowledge, } \\
\text { competence and skills of the future customs officers with taking } \\
\text { direction of professional activity into consideration. }\end{array}$ & $\begin{array}{l}\text { O.Metyolkina, } \\
\text { O. Nagorichna }\end{array}$ \\
\hline $\begin{array}{l}\text { Axiological principle } \\
\text { Professional training of the future customs officers is a process of } \\
\text { developing professional skills of the future Customs Service specialists } \\
\text { (epistemic-intellectual; social; moral-voluntary; emotional-regulate; } \\
\text { communicative; constructive and organizational) }\end{array}$ & $\begin{array}{l}\text { O. Samohval, } \\
\text { N. Tymchenko }\end{array}$ \\
\hline $\begin{array}{l}\text { Historical principle } \\
\text { Professional training of the future customs officers is a process of } \\
\text { practice, learning, improvement of the custom service order and } \\
\text { developing the moral and ethical qualities in custom house workers }\end{array}$ & $\begin{array}{l}\text { G. Potashnikova, } \\
\text { J. Rysich, } \\
\text { B. Novosad, } \\
\text { O. Morozov }\end{array}$ \\
\hline $\begin{array}{l}\text { Systematic-complex principle } \\
\text { Professional training of the future customs officers is a system of } \\
\text { knowledge acquisition, skills for its applying in different and } \\
\text { impermanent conditions of custom activities }\end{array}$ & $\begin{array}{l}\text { Y. Kunyev, } \\
\text { V. Popova }\end{array}$ \\
\hline
\end{tabular}

Within the competent principle as for professional training characteristic of the future customs officers, scientists have paid significant attention to various aspects of professional competence (social and psychological competence; communicative competence; structural and individual competence, etc.), considering that the process of learning and assimilation of general and specific knowledge, competence and skills, guiding the future specialists to perform concrete professional tasks and has to be aimed onto developing the professional competence.

A. Majcher-Teleon believes that professional training should be carried out in the process of continuing education within obtaining knowledge, skills, and competencies required for performing certain professional tasks, obtaining diplomas, certificates, titles to periodic training and retraining (Krajowe Ramy Kwalifikacji a Budowa Systemu Uczenia Się Przez Całe Życie, 2007).

A. Martsenyuk considers professional training of the future customs officers through developing the social and psychological competence as professional and personal characteristics (Марценюк, 2011).

Basing on the competent principle, A. Myropolska develops the model of professional competence in custom house workers. This model includes such blocks as: target setting, meaningful, functional, organizational, evaluation and final result; and also 
develops organizational and pedagogical conditions of effective developing of professional competence for customs officers: effective management by customs directors through the developing professional competence of specialists; practice the active forms and methods of training in the educational process with custom house workers; customs self-education (Миропольська, 2010).

Hereupon, the scientist of the competent principle consider the problem of professional training activity of the future customs officers in the aggregate of definitions as "social-psychological competence", "communicative competence" and "professional competence". However, scientists do not pay special attention to the features of the structure and content of professional training of the future custom house workers which are really significant in making characteristics of analyzed phenomenon.

Concerning the character of professional training of future customs officers the authors of the functional principle emphasize the practice of educational institutions that provide certain level of qualification according to the current needs and customs authority.

V. Chentsov considers that the process of preparing the customs officers should be based on established network of Customs Universities with the unified special educational program for all countries (Ченцов, 2009).

J. Jarmul, the scientist from the Republic of Poland, investigated training of future customs officer in the High School of Economics in Warsaw. The scientist observed that customs affairs, customs law, customs politics are the basic directions of customs training sphere. Specialists from the customs agencies have been regularly involved in teaching process in order to obtain skills and abilities both of theoretical practical nature (Wyższa Szkoła Ekonomiczna w Warszawie Szkołą Przyszłych Celników? 2001). This practice is very effective in Europe, but it is not widespread among higher education institutions in Ukraine.

In the article "Higher Customs School in the system of training of customs officers" Polish scientist J. Zhura notes that professional training involves development of personal student's qualities, acquisition of general knowledge about international relations and special knowledge on customs affairs (Wyższa Szkoła Celna w systemie kształcenia celników Józef Jura, 2002).

Thus, we can make a conclusion that studying the process of professional training of future customs officers the authors of functional principle pay more attention to the role of educational institutions and organizations that provide a specific necessary level of professionalism of the future custom officers.

As for the characteristics of the future customs officers' professional training, it is necessary to indicate that the authors of instrumental principle point out different technologies, methods, forms of educational process that contribute to effective process of studied phenomenon.

N. Kalynyuk considers the future training of customs house workers through the prism of forming professional and ethical competence of further border guards by using different methods of active learning (Калинюк, 2013).

O. Tryakina has noted in her works that professional training of the future customs officers is a process of skills acquisition to solve some common tasks of professional activity while putting professional duties into practice. The author proposes the development of professionally oriented disciplines for its realization ("international customs law", "electronic declaration", "fundamental principles of exportable control", "risk analysis in the customs business", "delivery control") considering the 
recommendations, implements, standards and best practices of the UN Economical Commission (Трякіна, 2013).

Consequently, scientists of the instrumental principle as for analysis the professional training of future customs officers single out learning the forms and methods in the studying of future professionals.

As for the characteristics of future customs officers' professional training, the authors of individual principle point out the development of personal qualities and characteristics required during the professional activities in the customs services.

A. Metyolkina claims that the process of future customs officers' professional training is a practice of learning through the student's personality with his cognitive activity, progressing of thinking, memory, attention and other cognitive processes (Метьолкіна, 2010).

The process of future customs officers' professional training was characterized by O. S. Nagorichna, Ukrainian scientist, as a specialized improvement of existing education, development, extension, outspreading and updating of professional knowledge, competence, skills within direction of professional activity (Нагорічна, 2007).

Therefore, concerning the characteristics of professional training of future customs officers as for its comparative analysis, scientists of individual principle pay their attention to creation of special psychological and pedagogical conditions for forming the individual and psychological characteristics that are really important in executing professional duties.

Scientists studying the axiological principle as for the characteristics of professional training of future customs officers, focus on the development of their professional skills.

M. Vuitovych describes the process of future customs officers' training as a system of formal education that gives future professionals the opportunity to get comprehensive experience, knowledge and ability to use them, performing tasks of professional direction, providing conditions for self-development skills, self-improvement, planning, organizing professional activities, team-working. (Zarządzanie Zasobami Ludzkimi w Służbie Celnej, 2011).

$\mathrm{N}$. Tymchenko considers the problem of the training future customs officers through the prism of forming professional and ethical features of further border guards that are necessary for successful professional business. The scientist has developed and implemented a methodology of forming professional and ethical qualities of future customs officers. In this methodology there are informative, organizational and activity components based on the structure of moral qualities, mechanism of moral norms transfer and principles in the internal acquisition of the students personality. It is also based on educational possibilities of educational process and using of active teaching methods complex (Тимченко, 2003).

In such a manner, within the confines of axiological principle as for the analysis of professional training of future customs officers, the scientists point out on professional qualities that are necessary for being successful specialist.

Looking to the experience of scientists of historical principle we can say that they emphasize the studying the process of the customs officers' professional training within the characteristics of the Customs Education.

The evolution of customs affairs and customs policy in Western Ukraine is represented in works of O. V. Morozov, B. M. Novosad, J. L. Rysich. On the basis of historical experience they point out the following: organizational and legal basis of the customs work at the end of XIXth century; rising of the export potential of Ukrainian 
provinces; the meaning and appointment of customs policy and customs authorities in the state mechanism and their tasks (Рисіч, Новосад, Морозов, 2000).

Thus, the scholars of historical principle characterize the customs system of education throughout studied periods, taking into consideration the terms of the customs policy.

Scientists researching the systematic-complex principle as for the characteristics of professional training of future customs officers, analyze training system which guarantees optimal and sequential knowledge level of customs officer focusing his attention on interdisciplinary connections.

Y. Kunyev has noted in her works that professional training of the future customs is a system of learning professional knowledge, skills for its applying in a diverse and rapidly changing conditions of customs activity (Кунєв, 2006).

$\mathrm{V}$. Popova considers that the most important in forming the professional training system is the principle of practical orientation curriculum and program for professionals customs authorities; the principle of organization of vocational training, which is based on scientific and analytical supplying, upgrading and requires systematic diagnosis of the professionalism level of the customs officers, identifying emerging issues and evaluate the educational process (Попова, 2013).

Consequently, scientists of systematic-complex principle as for the characteristics of professional training of future customs officers have devoted attention to the system of training for professionals of Customs Service, which provides practical orientation with curriculum and programs, scientific and analytical aspects of the educative process, identifies problems and evaluation of the educational process.

As it can be seen, among the scientific approaches indicated above the theoretical analysis of the issues dedicated to customs officers' professional training has revealed that most scientists characterize it as a process of training, organization, formation of professionalism of future customs officials providing them with the necessary knowledge, skills and proficiencies; some scientists compare the training of future customs officers with the process of future customs officers' professional qualities formation

In our view, professional training of customs officers is the process of learning, setting up general and special knowledge, skills and proficiencies of future customs officials, who perform the functions of future professional activities, fulfil their functions in accordance with their professional duties during customs service.

\section{CONCLUSIONS}

As a result we can make a conclusion that an overview of the multifaceted literature has allowed to present and describe major theoretical approaches of Ukrainian and Polish scientists to professional training of future customs officers. Within each of the abovementioned approaches, it has been emphasized that professional training of future customs officers is determined by personal, practical, functional and historical character, as it is becoming important both in the process of understanding this phenomenon and its research and development.

So, despite the fact that training of future customs officers has been carried out in Ukraine at a sufficient level for many years, it should be constantly improved, taking into account the best achievements of international experience, including the experience of higher educational institutions in Poland. 


\section{REFERENCES}

1. Jarmul, J. (2001) Wyższa Szkoła Ekonomiczna w Warszawie Szkoła Przyszłych Celników? [Higher School of Economics in Warsaw is the School for Customs Officers?]. Monitor Prawa Celnego. Retrieved 12.08.2014 from : http://www.monitorc.pl/roczniki/2001/CEL-4-4.pdf (in Polish).

2. Калинюк, Н. В. (2013). До проблеми формування та розвитку професійної комунікативної компетентності майбутніх офіцерів-прикордонників [The problem of formation and development of professional communicative competence of the future officers-borderguards]. Вісник Національної академії Державної прикордонної служби України [Bulletin of the National Academy of State Border Guard Service of Ukraine]. No 3, p.14-18. Retrieved 25.06.2013, from : http://nbuv.gov.ua/jpdf/Vnadps_2013_3_11.pdf(in Polish).

3. Кунєв, Ю. Д. (2006). Основні напрями та шляхи удосконалення кадрового забезпечення митної служби Украӥни [The main directions and ways to improve employees of the Customs Service of Ukraine]. Customs Affairs, No 1, p. 51-56 (in Ukrainian).

4. Марценюк, О. О. (2011). Розвиток сочіально-психологічної компетентності працівників Державної митної служби України [Development of the social-psychological competence of the officials of the State Customs Service of Ukraine]. Candidate thesis. Dnipropetrovs'k Regional Institute of Public Administration of the National Academy of Public Administration under the Office of the President of Ukraine, p. 20 (in Ukrainian).

5. Метьолкіна, О. М. (2010). Особистісно-діяльнісний розвиток студентамитника в курсі навчальної дисципліни «іноземна мова» [Personality-action development of the student-customs officer in the foreign language course]. Teaching languages in higher educational institutions, No 17, p. 110-116 (in Ukrainian).

6. Миропольська, О. В. (2010). Формування професійної компетентності фахівиів митних органів в умовах службової діяльності [The formation of the Customs Officials Professional Competence in the Conditions of Service Activities]. Candidate thesis. The National Academy of the State Border Guard Service of Ukraine named after Bohdan Khmelnytskyi, Khmelnytskyi, p. 20 (in Ukrainian).

7. Нагорічна, О. С. (2007). Компоненти та критерї̈ готовності працівників митних органів до професійної діяльності [Components and criteria of readiness of customs officials related to their professional activity]. Collection of works. National academy of the State border service of Ukraine named Bohdan Khmelnytskyi, No 39, p. 120-122 (in Ukrainian).

8. Попова, В. Е. (2013). Проблемы формирования и совершенствования кадрового потенииала таможенной службы Российской Федерачии [Problems of formation and improvement of staff capacity of the customs service of the Russian Federation]. Problems of Modern Economics, No 1, p. 231-233 (in Ukrainian).

9. Рисіч, Й., Новосад, Б., Морозов, О. (2000). Історія митной справи та митної політики в Украӥні [The history of customs affairs and customs policy in Ukraine]. Дніпропетровськ : Академія митної служби України, p. 68 (in Ukrainian).

10. Самохвал, О. О. (2009). Формування професійних якостей майбутніх менеджерів митної служби у проиесі фахової підготовки [The Formation of Future Customs Managers' Professional Qualities in the Process of Vocational Training]. 
Candidate thesis. Vinnytsya state pedagogical university named after Mihailo Kotsubinskiy, p. 20 (in Ukrainian).

11. Тимченко, Н.С.(2003).Формування професійно-етичних якостей майбутніх службовиів-митників [The formation of the professional - ethical qualities of the future Customs official]. Abstract of Cand. Sci. (Ped.) thesis. Центр. ін-т післядиплом. пед. освіти АПН України, р. 20 (in Ukrainian).

12. Трякіна, О. О. (2013). Нові технології навчання дисциплін митного спрямування в прочесі професійної підготовки магістрів за спечіальністю «Право» [New technologies of training of customs-oriented subjects during professional training of masters of customs in law]. Retrieved 29.03.2013 from : http://nbuv.gov.ua/jpdf/vlup 2013 15 14.pdf (in Ukrainian).

13. Ченцов, В. В. (2009). Досвід професійної підготовки кадрів для митної служби [The experience of professional training of Customs Service staff]. In: Proceedings of the International scientific practical conference "Actual problems of training of judges, prosecutors and law enforcement officers" (April, 23, 2009). Kуiv: Генеральна прокуратура України, Національна академія прокуратури України р. 45-46 (in Ukrainian). 